\title{
A child with partial trisomy of chromosome 17 and partial monosomy of chromosome 3: 46,XY,der(3),t(3;17)(p25;q23)
}

\section{J SHAWE, CLAUDINE FEAR*, AND W J APPLEYARD} Department of Paediatrics, Kent and Canterbury Hospital, Canterbury CT1 3NG; and *the Paediatric
Research Unit, Guy's Hospital, London SE1 9RT.

SUMMARY A male infant with multiple congenital abnormalities and global retardation was found to have a translocation resulting in partial trisomy for the distal end of the long arm of chromosome 3 . The phenotypically normal father carried a balanced reciprocal translocation between chromosomes 3 and 17 .

A number of cases have been described with partial trisomy $17 \mathrm{q}$, but none is associated with partial monosomy $3 \mathrm{p}$. The child presented below has clinical features similar to those found in partial trisomy for $17 \mathrm{q}$, whereas the contribution of the small $3 p$ deletion is less easy to ascertain.

\section{Case report}

The proband, a male infant, was born after a normal

Received for publication 4 November 1981

Accepted for publication 16 March 1983. pregnancy, by Caesarian section for breech presentation, to a 20-year-old primigravid motlier and 24-year-old father. The parents were non-consanguineous, healthy, and of normal intelligence. Physical examination (fig 1) revealed a large anterior fontanelle, wide sagittal suture, narrow biparietal diameter, low set malrotated ears, mongoloid slant to the eyes, epicanthic folds, hypertelorism, broad nasal bridge, high arched palate, wide mouth, micrognathia, low posterior hairline, webbed neck, short proximal limbs, postaxial polydactyly of hands and feet, sacral dimple, cryptorchidism, rocker bottom feet, and a heart murmur. An intravenous pyelogram, electrocardiogram, and ultrasound of the ventricles were normal. Skeletal survey revealed abnormal sclerosis of the long bones, rudimentary bilateral sixth fingers, poor mineralisation of the skull vault, and a wide 'short chest'.

Review at 19 months revealed head circumference $46.2 \mathrm{~cm}$, height $70 \mathrm{~cm}$, and weight $8 \cdot 11 \mathrm{~kg}(<3 \mathrm{rd}$

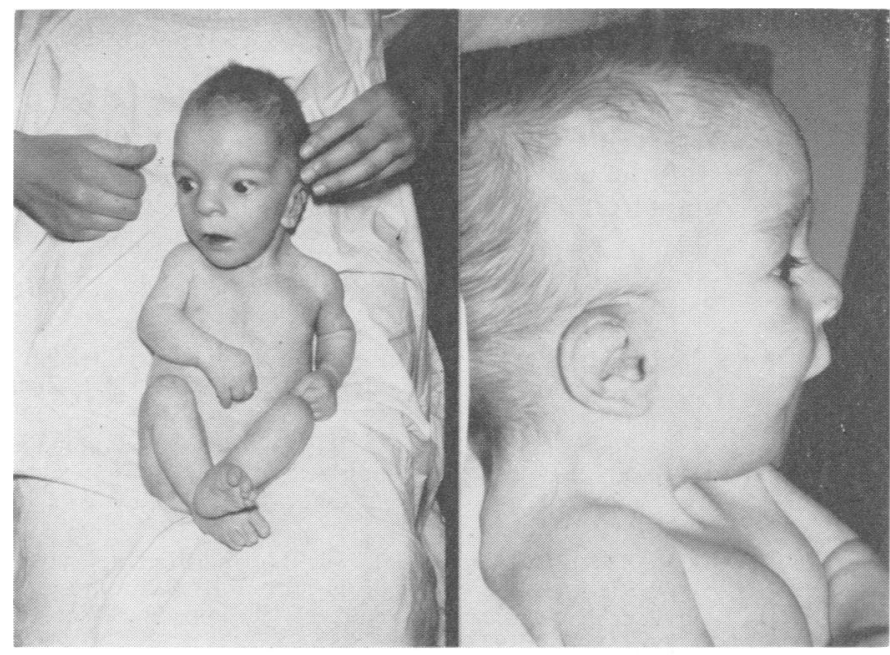

FIG 1 The proband. 
centile), with little change at 30 months. Developmental assessment on the latter occasion showed significant delay, with all skills at a 5-month level.

\section{CYTOGENETIC FINDINGS}

Peripheral blood lymphocytes were cultured from the proband and both parents for chromosome studies with trypsin $G$ banding. The proband showed an unbalanced chromosome rearrangement involving chromosome 3 (fig 2). Examination of the paternal chromosomes showed a balanced translocation between the short arms of chromosome 3 and the long arms of chromosome 17 (fig 2). His karyotype was $46, \mathrm{XY}, \mathrm{t}(3 ; 17)(\mathrm{p} 25 ; \mathrm{q} 23)$ and that of the proband $46, \mathrm{XY}, \operatorname{der}(3), \mathrm{t}(3 ; 17)(\mathrm{p} 25 ; \mathrm{q} 23)$, resulting in partial monosomy of $3 p$ and partial trisomy of $17 q$. The maternal chromosomes were normal.

\section{Discussion}

This child has partial trisomy for $17 \mathrm{q} 22 \rightarrow 17 \mathrm{qter}$ and partial monosomy for 3 p $25 \rightarrow 3$ pter, a combination not previously described.

Partial trisomy for $17 \mathrm{q}$ is rare. A patient with pure trisomy for this section of $17 \mathrm{q}$ has been described by Fryns et $a l,{ }^{1}$ while the first report was that of Fouquette $e t a l^{2}$ who, in 1974, identified a duplication of $17 \mathrm{q}$ using fluorescence. Berberich et $\mathrm{al}^{3}$ reported three affected persons in a family where a $7 \mathrm{q} ; 21 \mathrm{q}$ reciprocal translocation was segregating.

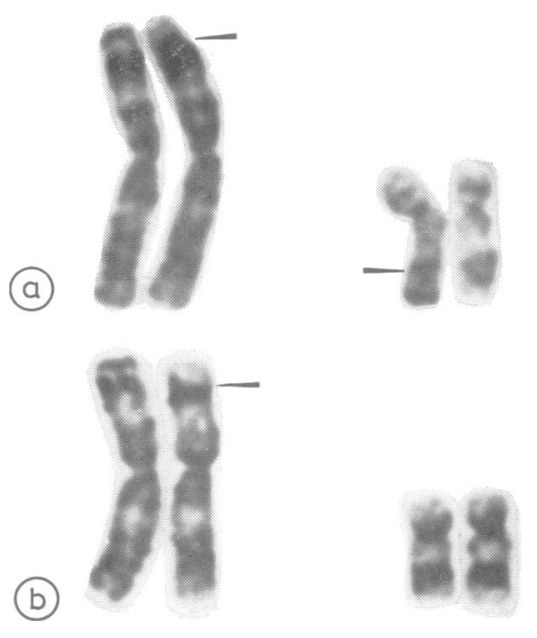

FIG 2 Partial karotypes of father and proband. (a) Paternal balanced translocation $(3 ; 17)(p 25 ; q 23)$. (b) Proband's unbalanced translocation der $(3),(3 ; 17)(p 25 ; q 23)$ pat.
TABLE Comparison of clinical features in present case with those previously reported.

\begin{tabular}{llll}
\hline & $\begin{array}{l}\text { Present } \\
\text { case }\end{array}$ & $\begin{array}{l}\text { Cases of } \\
\text { trisomy } \\
17 q 22 \rightarrow \\
17 q \text { ter }^{134}\end{array}$ & $\begin{array}{l}\text { Other cases } \\
\text { of } 17 q \\
\text { duplication } 25\end{array}$ \\
\hline Mental retardation & + & $5 / 5$ & $2 / 2$ \\
Growth retardation & + & $5 / 5$ & $1 / 2$ \\
Long head, narrow anteriorly & + & $4 / 5$ & $1 / 2$ \\
Wide open sagittal suture & + & $-5 / 5$ & $-1 / 2$ \\
Low set malrotated ears & + & $4 / 5$ & $2 / 2$ \\
Epicanthic folds & + & $3 / 5$ & $1 / 2$ \\
'Squinty' eyes & - & $4 / 5$ & $1 / 2$ \\
Wide mouth & + & $4 / 5$ & $2 / 2$ \\
High arched or cleft palate & + & $4 / 5$ & $1 / 2$ \\
Micrognathia & + & $2 / 5$ & $1 / 2$ \\
Webbed neck & + & $4 / 5$ & $0 / 2$ \\
Low posterior hairline & + & $5 / 5$ & $1 / 2$ \\
Polydactyly & + & $1 / 5$ & $0 / 2$ \\
Short proximal limbs & + & $1 / 5$ & $0 / 1$ \\
Cryptorchidism & + & $2 / 3$ & $2 / 2$ \\
Congenital heart disease & - & $2 / 5$ & $0 / 2$ \\
Renal anomaly & - & $2 / 5$ &
\end{tabular}

Turleau et $a l^{4}$ described a child with trisomy for the same region of $17 q$ and a deletion of $5 p$. The main clinical features in these subjects are summarised in the table. A number of features are common to all. Also included in the table is the child described by Fouquette $e t a l^{2}$ and one reported by SalamanceGomez and Armendares. ${ }^{5}$

The only description of a subject monosomic for the distal part of $3 p$ is an infant described by Verjaal and De Nef. ${ }^{6}$ The clinical features of this child were quite distinct from those of our case, apart from the abnormal ears, high palate, and undescended testes, common to many chromosomally abnormal infants.

This case supports the suggestion of Turleau et $a l^{4}$ that trisomy $17 \mathrm{q} 22 \rightarrow 17 \mathrm{qter}$ is a recognisable condition whose chief features are a narrow head, wide mouth, neck webbing, low posterior hairline, and polydactyly.

We wish to thank Dr Caroline Berry for her help 을 with the manuscript. This work was supported by a grant from the DHSS.

\section{References}

1 Fryns JP, Parloir C, Van den Berghe H. Partial trisomy $\omega$ 17q. Karyotype 46XY $\operatorname{der}(21) t(17 ; 21)(\mathrm{q} 22 ; \mathrm{p} 13)$. Hum Genet 1979;49:361-4.

2 Fouquette B, Rosenfeld R, Cadotte M. Anomalie morphologique par duplication d'un chromosome $\stackrel{\$}{\oplus}$ $17(46 \mathrm{XY} 17 \mathrm{q}+)$ chez un nouveau-né. Union Med Can $1974 ; 103: 1404$.

3 Berberich MS, Carey JC, Lawce HJ, Hall BD.Duplication

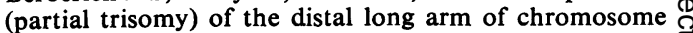
17: a new clinically recognizable chromosome disorder. Birth Defects 1978;XIV,6C:287-95. 
4 Turleau C, de Grouchy J, Bouveret JP. Distal trisomy 17q. Clin Genet 1979;16:54-7.

5 Salamance-Gomez F, Armedares S. Identification of isochromosome 17 in a girl with mental retardation and congenital malformations. Ann Genet (Paris) 1975;18: 235-8.

6 Verjaal M, De Nef J. A patient with a partial deletion of the short arm of chromosome 3. Am J Dis Child 1978; $132: 43-5$.

Correspondence and requests for reprints to Dr D J Shawe, Undercleave Farm, Little Torrington, North Devon.

\title{
De novo translocation heterozygote with three reciprocal translocations
}

\author{
J L WATT AND D A COUZIN \\ Department of Genetics, University of Aberdeen, Medical School Buildings, Foresterhill, \\ Aberdeen AB9 2ZD.
}

SUMMARY An extremely rare case of a child with three balanced reciprocal translocations involving six different autosomes is described. These abnormalities have apparently arisen de novo and seem to have only relatively minor phenotypic effects. The meiotic possibilities are discussed and cytogenetic markers suggest that the damage may have occurred in a paternal gamete.

It is rare to find more than a single translocation in a person $^{1}$ and extremely rare to find more than two. ${ }^{2}$ Complex chromosome rearrangements involving exchanges between three or more chromosomes in a circular fashion show certain similarities to the present case, in that as many as four or five derived chromosomes can be seen in the karyotype of the carrier. $^{34}$ The observation of six de novo abnormal chromosomes in a live-born child is unrecorded to the best of our knowledge.

\section{Case report}

This boy presented at the age of 9 years because of maternal anxiety about his short stature. It was reported that he had always been short and had been overtaken by his sister who is 2 years younger at the age of 5 years. At the age of 10 years his height was $4 \mathrm{~cm}$ below the $3 \mathrm{rd}$ centile, and his height velocity over the previous year had been just below the 10th centile. Radiology at this time showed his bone age to be about 2 years delayed.

Despite this problem he was found to be a healthy, well proportioned boy whose performance at school

Received for publication 1 February 1983. Accepted for publication 10 March 1983. was average. He showed no indications of malabsorption. Both his parents and his two sisters were of average height and no one else in the family was reported to have short stature. There was no evidence of consanguinity.

The mother appeared to have had a normal uneventful pregnancy and an induced birth at 38 weeks' with normal delivery. At birth the child was found, at $2497 \mathrm{~g}$, to be $100 \mathrm{~g}$ below the 10th centile. The neonatal period was normal and developmental progress was satisfactory, if a little slow. His intelligence remained normal but his speech was rather slow and he had been given speech therapy at 4 years of age.

\section{Materials and methods}

Chromosome preparations were made from conventional phytohaemagglutinin stimulated cultures of whole blood. The metaphases were $G$ banded $^{5}$ and sequentially $\mathrm{C}$ banded. ${ }^{6}$

\section{Results}

One hundred cells were examined revealing a grossly abnormal karyotype: $46, \mathrm{XY}, \mathrm{t}(1 ; 7)(\mathrm{q} 42 ; \mathrm{q} 22)$, $\mathrm{t}(5 ; 9)(\mathrm{q} 31 ; \mathrm{q} 32), \mathrm{t}(13 ; 16)(\mathrm{q} 21 ; \mathrm{q} 22)$ (figs 1 and 2 ). The three translocations appeared to be reciprocal and balanced. Parental karyotypes were normal.

Comparison of $\mathrm{C}$ band polymorphisms showed that the derived chromosomes der (1), der (9), and der (16) were of paternal origin while the normal homologues were from the mother (fig 2). In addition, the mother had a marker chromosome 13ps+ which was unaltered in the child, while the father had a marker chromosome $5 \mathrm{ph}+$ which could be identified as the derived chromosome 5 in the child 